\title{
Disorders caused by chromosome abnormalities
}

\author{
This article was published in the following Dove Press journal: \\ The Application of Clinical Genetics \\ 9 November 2010 \\ Number of times this article has been viewed
}

\section{Aaron Theisen \\ Lisa G Shaffer \\ Signature Genomic Laboratories, Spokane, WA, USA}

Correspondence: Lisa G Shaffer

Signature Genomic Laboratories, $2820 \mathrm{~N}$

Astor St, Spokane, WA 99207, USA

Tel + I 5094746840

Fax + I 5094746839

Email shaffer@signaturegenomics.com

\begin{abstract}
Many human genetic disorders result from unbalanced chromosome abnormalities, in which there is a net gain or loss of genetic material. Such imbalances often disrupt large numbers of dosage-sensitive, developmentally important genes and result in specific and complex phenotypes. Alternately, some chromosomal syndromes may be caused by a deletion or duplication of a single gene with pleiotropic effects. Traditionally, chromosome abnormalities were identified by visual inspection of the chromosomes under a microscope. The use of molecular cytogenetic technologies, such as fluorescence in situ hybridization and microarrays, has allowed for the identification of cryptic or submicroscopic imbalances, which are not visible under the light microscope. Microarrays have allowed for the identification of numerous new syndromes through a genotype-first approach in which patients with the same or overlapping genomic alterations are identified and then the phenotypes are described. Because many chromosomal alterations are large and encompass numerous genes, the ascertainment of individuals with overlapping deletions and varying clinical features may allow researchers to narrow the region in which to search for candidate genes.
\end{abstract}

Keywords: chromosome, deletion, duplication, telomere, segmental duplication

\section{Introduction}

Humans have 23 pairs of chromosomes, ie, one pair of sex chromosomes ( $\mathrm{X}$ and/or Y) and 22 pairs of autosomes (chromosomes 1-22). Many human genetic disorders result from unbalanced chromosome abnormalities, in which there is a net gain or loss of genetic material. Numeric and structural chromosomal abnormalities occur in approximately $0.6 \%$ of live births, ${ }^{1}$ and often result in dysmorphism, malformations, and/or developmental disabilities. The resulting phenotypes are caused by the imbalance of one or more dosage-sensitive genes in a particular chromosome or chromosomal segment. Such gene imbalances often have devastating consequences and cause $25 \%$ of all miscarriages and stillbirths, and 50\%-60\% of first-trimester miscarriages. ${ }^{2}$

Numeric abnormalities, or aneuploidies, result from the gain or loss of an entire chromosome. Most aneuploidies result from improper segregation of the chromosome pairs during meiosis. Numeric abnormalities comprise the most common cytogenetic abnormalities. Numeric abnormalities are more tolerated for the sex chromosomes and only certain autosomes. The most common monosomy is that for the X chromosome $(45, \mathrm{X})$ found in Turner syndrome. Trisomy, the presence of three, rather than two, copies of a particular chromosome, causes Down syndrome, or trisomy 21 , and occurs in about 1/800 live births. Other common trisomies include trisomy 13 and 18. Mosaicism for a normal cell line and an abnormal cell line may occur in a single 
individual. Certain trisomies, such as trisomy 8 and 9, rarely occur in all cells and are mostly found in individuals with mosaicism.

In contrast with numeric abnormalities, structural chromosomal abnormalities result from the breakage and subsequent reunion of chromosome arms. Some structural chromosome abnormalities result in gain or loss of material. Deletions involve the loss of a segment of a chromosome and duplications result in a gain of a chromosome segment. Deletions may be terminal or interstitial; a terminal deletion results after one break in the chromosome with loss of the segment distal to the break, whereas an interstitial deletion results after two breaks in the chromosome, with the loss of the intervening segment, and rejoining of the remaining chromosome segments. A duplication is caused by the gain of a copy of a chromosomal segment at the original location on the chromosome. Duplications may be in an inverted orientation or in the original (direct) orientation.

Other structural chromosome abnormalities do not result in gain or loss of any genetic material. Such rearrangements include inversions, which are caused by a twobreak event and the end-to-end reversal of the intervening chromosomal segment; translocations, which result from the exchange of chromosome segments between two or more chromosomes; and insertions, which occur when a segment of one chromosome is translocated and inserted into a new region of the same chromosome, the other homolog, or a nonhomologous chromosome. These rearrangements may be pathogenic if a gene(s) is disrupted by a rearrangement breakpoint, a novel fusion gene product is formed, or a position effect is exerted on genes neighboring the rearrangement.

Compared with, for example, single-gene mutations, chromosome abnormalities often disrupt large numbers of developmentally important genes. Such imbalances may alter the dosage of genes expressed within the affected chromosomal segment, resulting in clinical consequences for the individual (see Table 1). Some imbalances result in a contiguous gene syndrome, in which multiple genes within the deleted or duplicated region are affected, each contributing a discrete clinical feature to the phenotype. ${ }^{3}$ Alternately, some chromosomal syndromes may be caused by a deletion or duplication of a single gene with pleiotropic effects. For most deletion syndromes, deletion causes haploinsufficiency of a gene or genes in the region, in which the remaining intact copy of the gene does not produce sufficient gene product for normal function. Haploinsufficiency for specific genes has been identified in several syndromes, including Williams syndrome, Langer-Giedion syndrome, Miller-Dieker syndrome, and DiGeorge/velocardiofacial syndrome.

Traditionally, chromosome abnormalities were identified by visual inspection of the chromosomes under a microscope. Each chromosome can be divided into bands, which are sections of a chromosome that can be distinguishable from adjacent sections by lighter or darker variations in intensity following one or more staining methods. The original reports of chromosome rearrangements were made prior to the development of these staining techniques. Thus, any rearrangements recognized under the microscope were either numeric or an altered segment of the chromosome large enough so that the affected homolog could be easily distinguished from the normal homolog based on the overall size of the chromosome. ${ }^{4,5}$ The development of banding techniques and high-resolution chromosome analysis enabled the detection of subtle rearrangements that affected one or a few chromosome bands. The use of molecular cytogenetic technologies, such as fluorescence in situ hybridization (FISH) and microarrays, has allowed for the identification of cryptic or submicroscopic imbalances, which are not visible under the light microscope (Figure 1). Numerous previously unrecognized microdeletion and microduplication syndromes have been identified by these molecular cytogenetic techniques. ${ }^{6-16}$

In 1986, Schmickel $^{3}$ first described contiguous gene syndromes (CGS) as involvement of multiple genes located in close proximity to each other on a chromosome. This term has been refined over the years and expanded to include a group of disorders defined by a deletion or duplication of a chromosomal segment spanning more than one disease gene, each affecting the phenotype independently. CGS have been described for many disorders mapping to various chromosomes. Disorders now recognized as CGS often have subtle cytogenetic changes that cannot always be resolved with conventional cytogenetic methods. Molecular cytogenetics, specifically FISH and microarray analysis, has helped to characterize many CGS.

\section{Terminal rearrangements}

Of all cytogenetically visible structural abnormalities, the majority occur in the distal telomeric bands of the chromosomes. ${ }^{17}$ Telomeres are specialized protein-DNA structures at the ends of all linear chromosomes that play numerous important cellular roles, including the prevention of chromosome degradation and end-to-end chromosome fusions, ${ }^{18}$ as well as the proper pairing, recombination, and segregation of chromosome homologs during meiosis. ${ }^{19}$ 


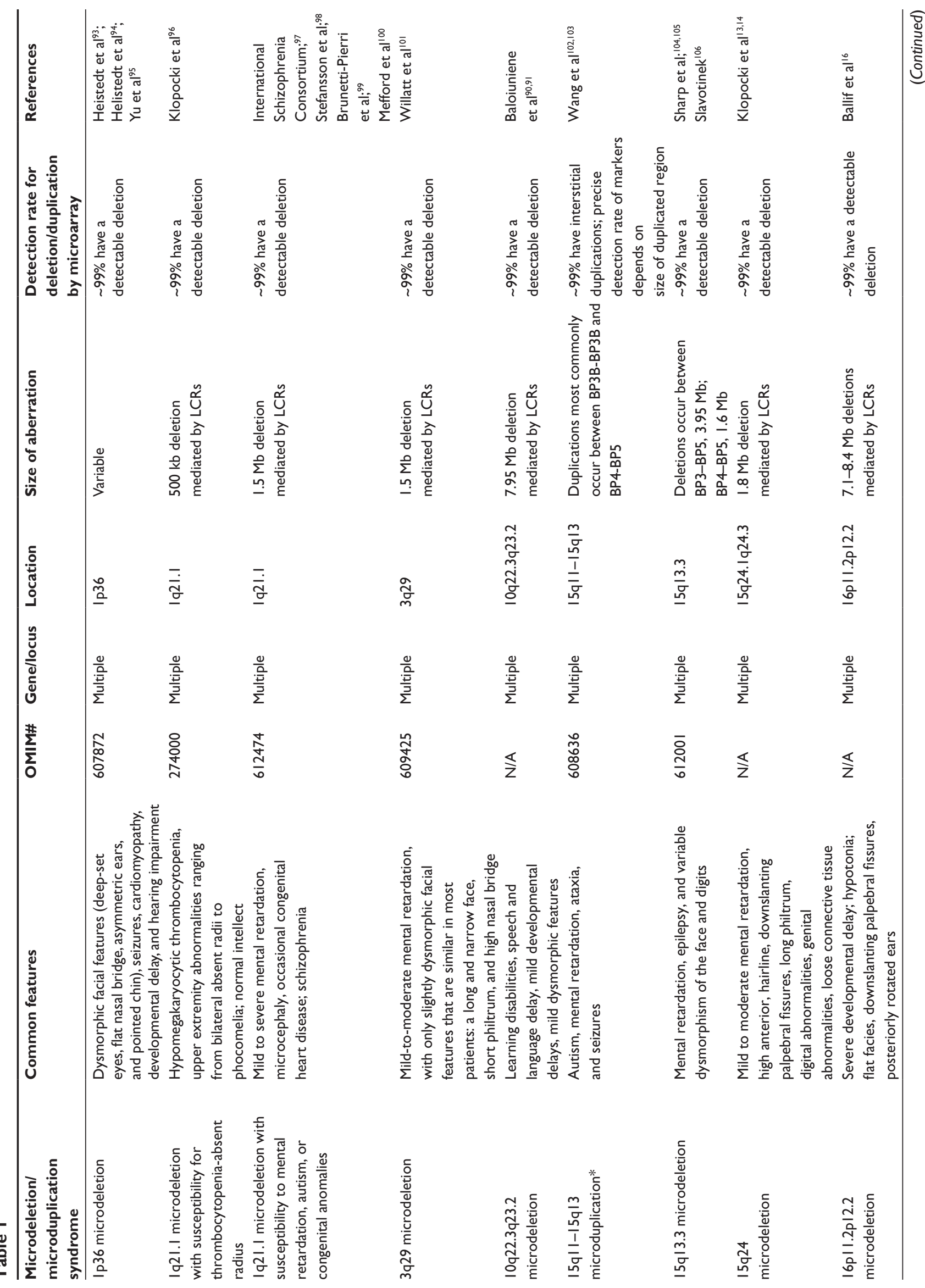




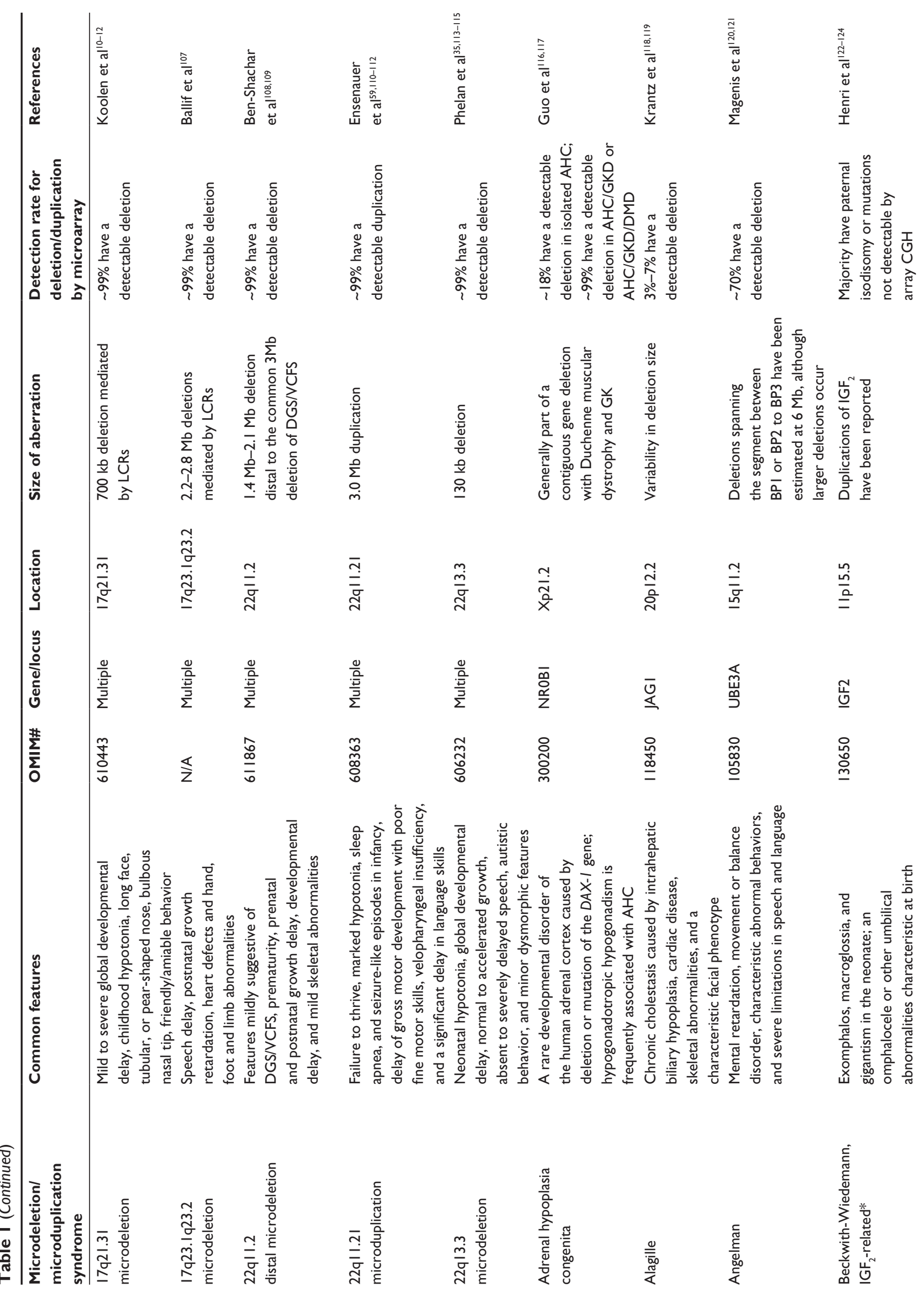



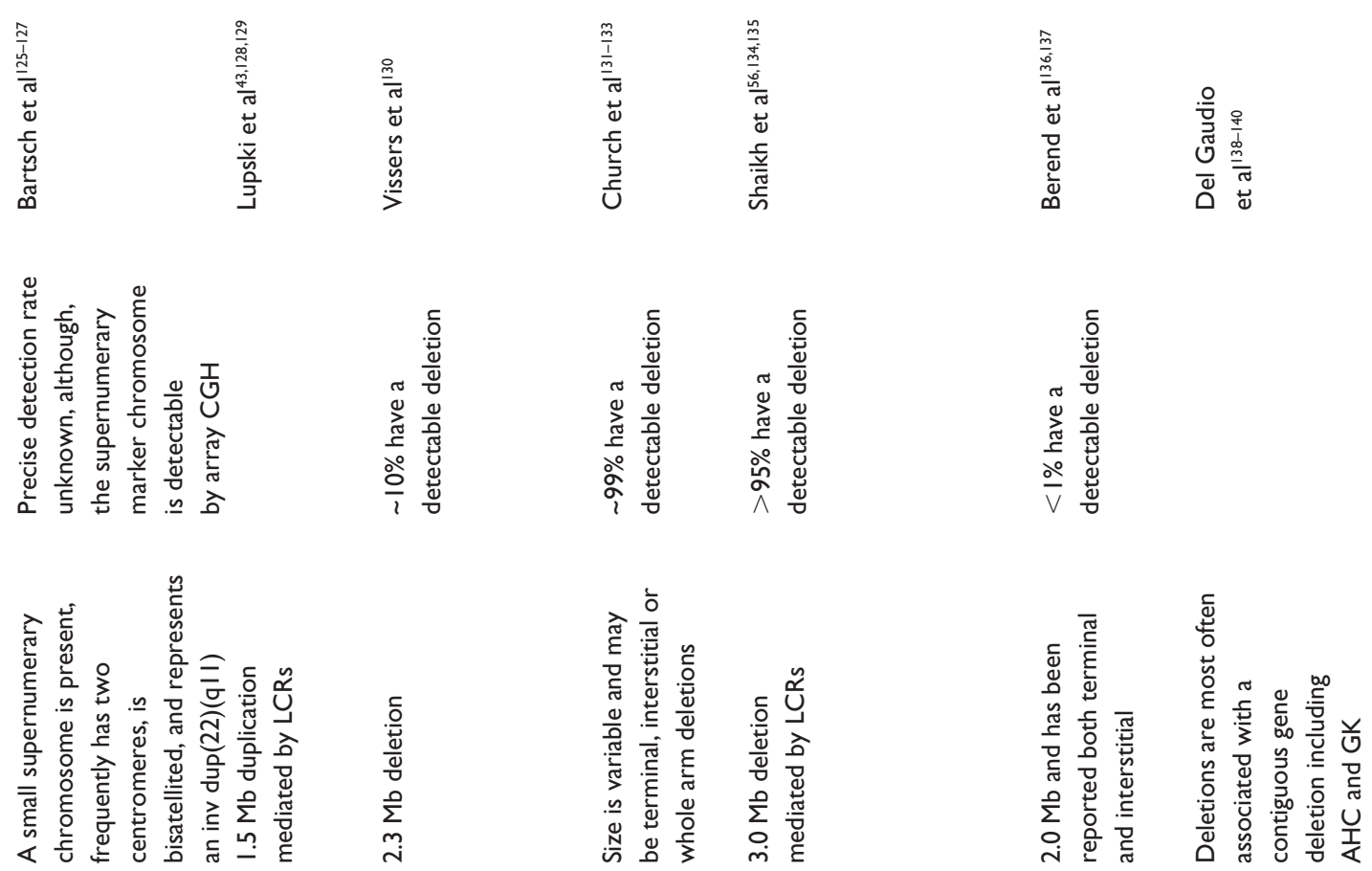

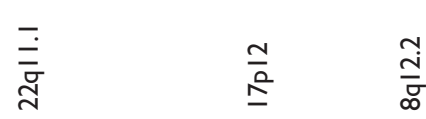

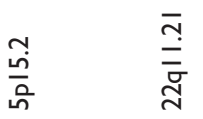

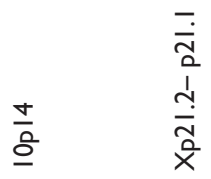

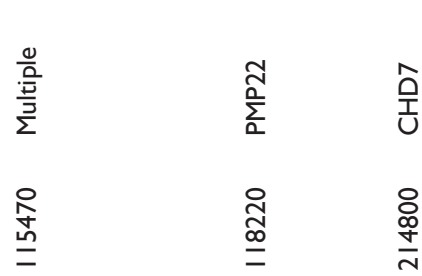

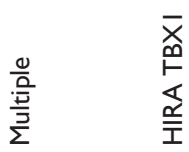

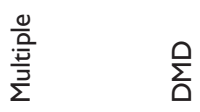

总

$\frac{\stackrel{0}{0}}{\frac{m}{0}} \quad \frac{8}{m}$

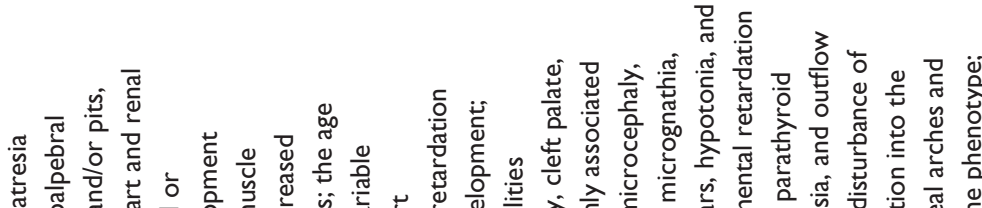

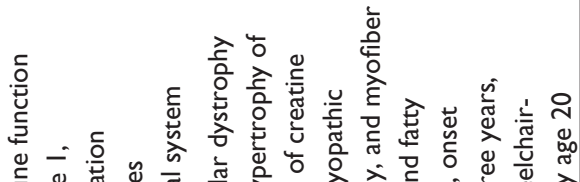

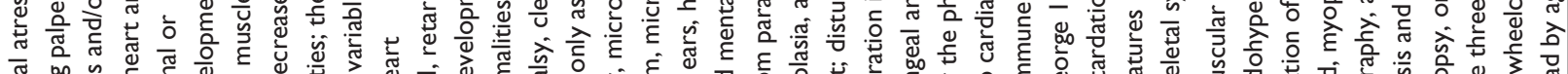

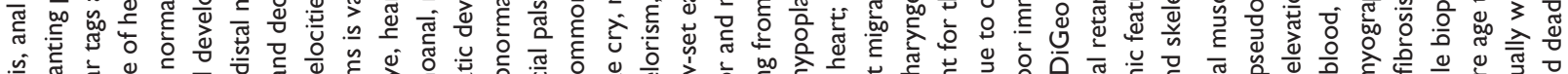

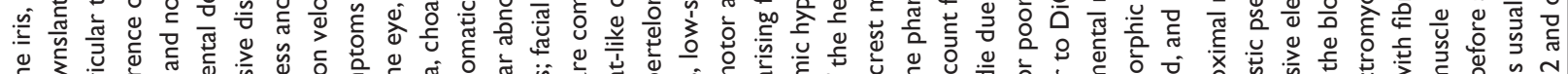

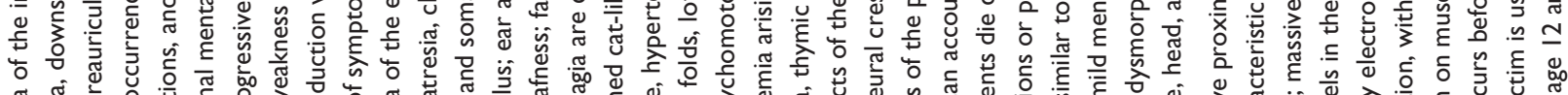

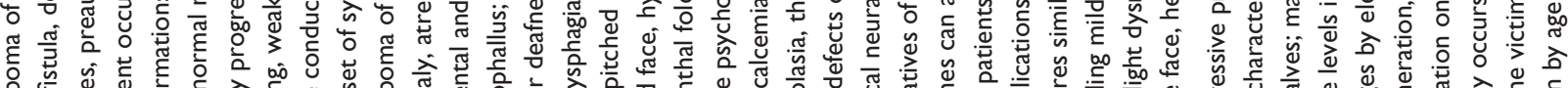

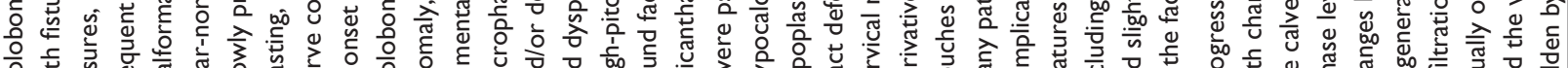

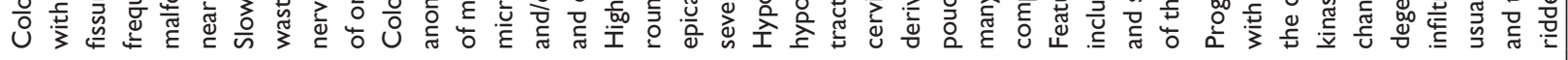
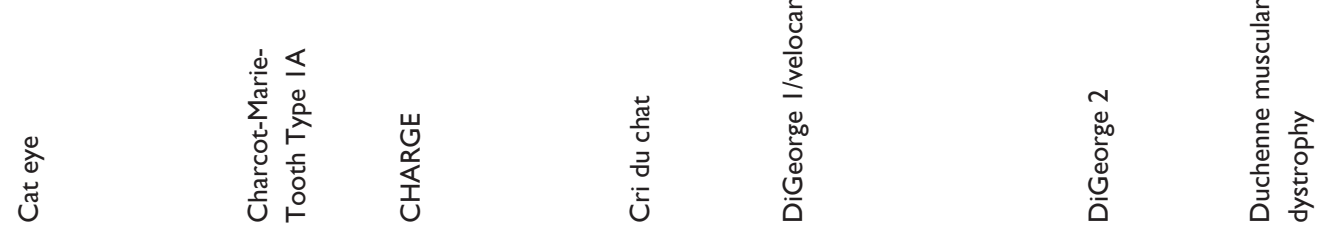


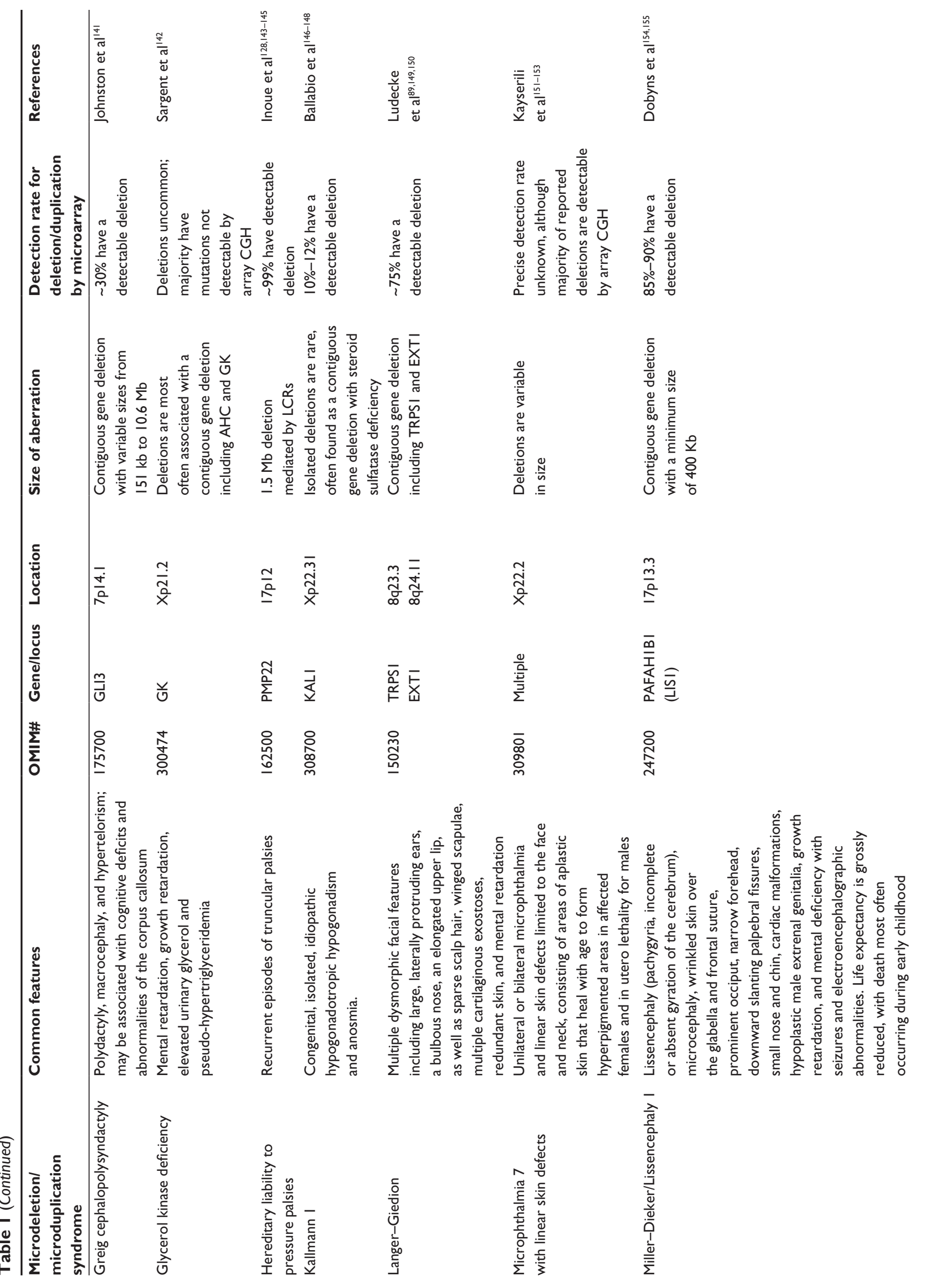




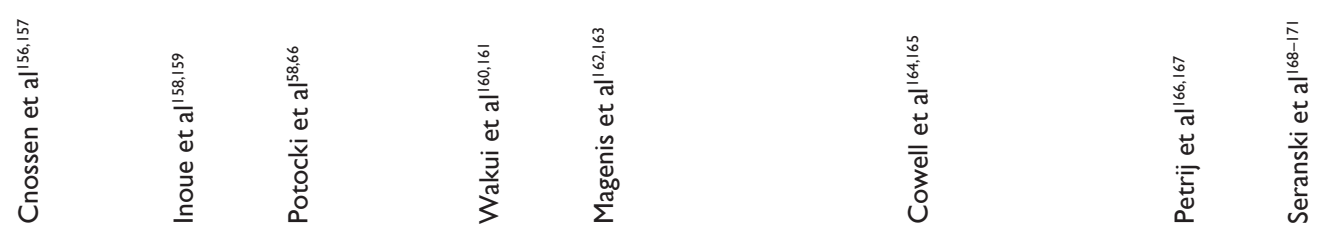
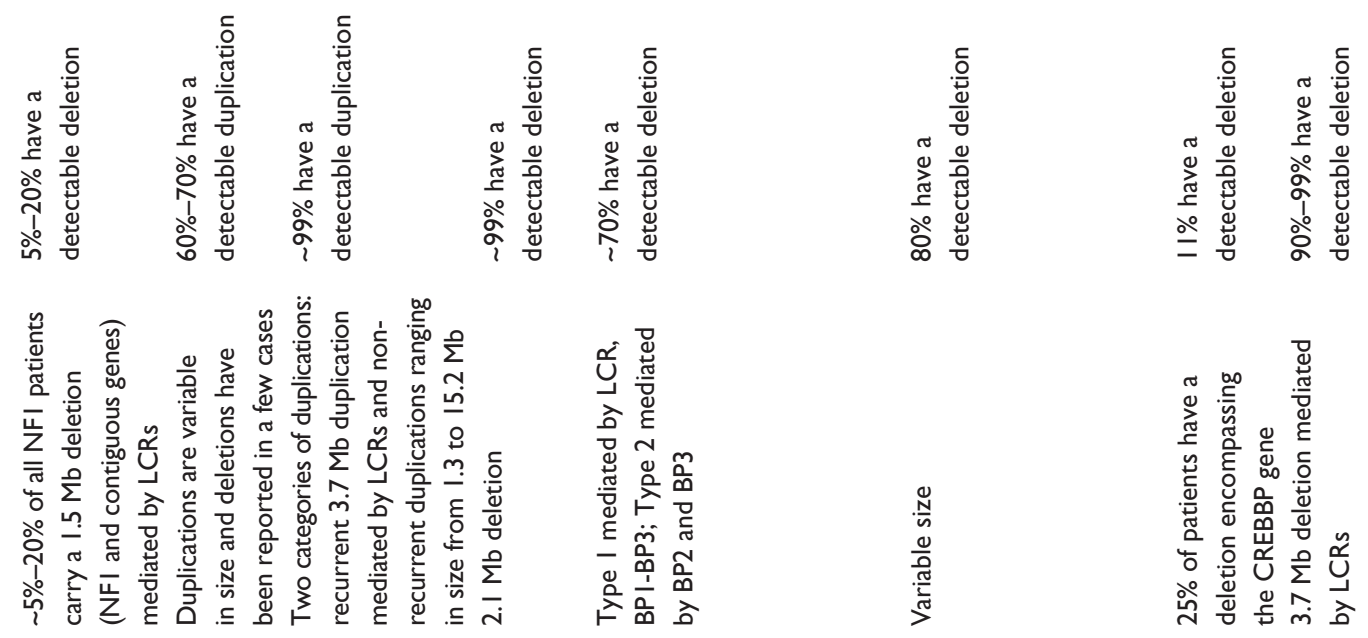

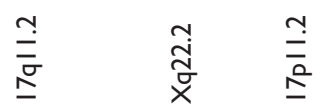
$\stackrel{\stackrel{ }{\overline{0}}}{\stackrel{ }{\overline{0}}}$

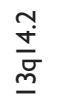
$\stackrel{m}{\frac{m}{0}} \stackrel{\stackrel{ }{\overline{0}}}{\underline{\underline{0}}}$

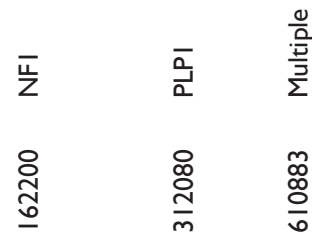

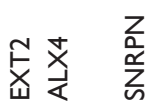
$\bar{\Phi}$
总
咅

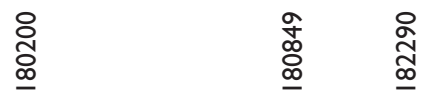
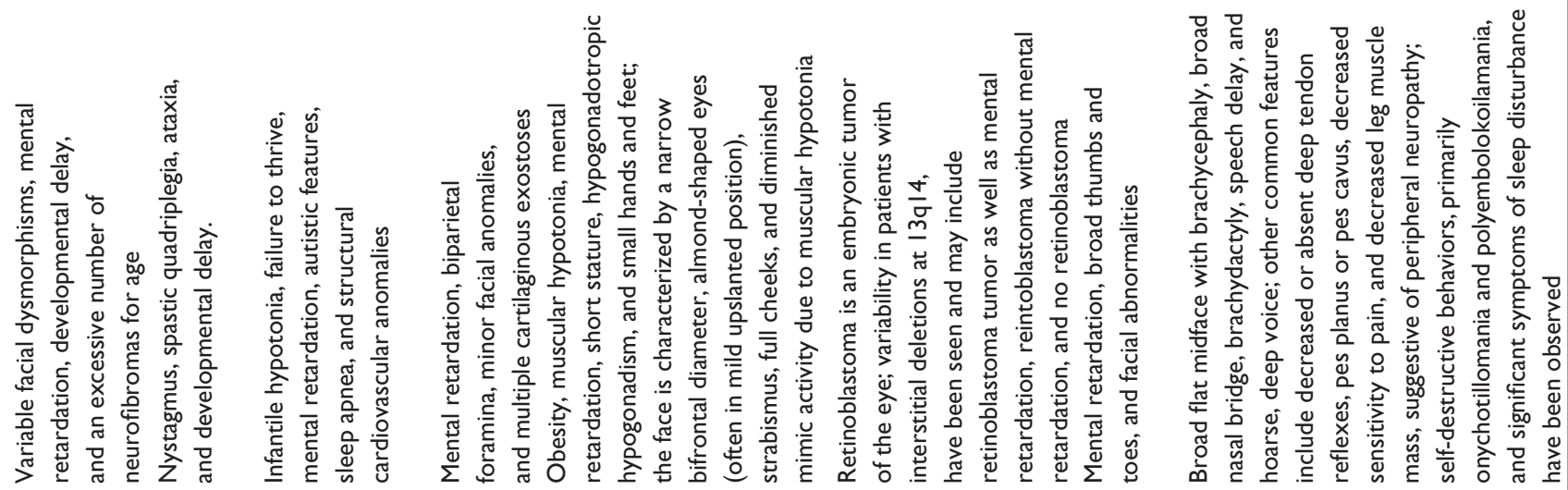

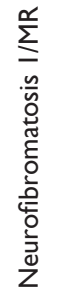
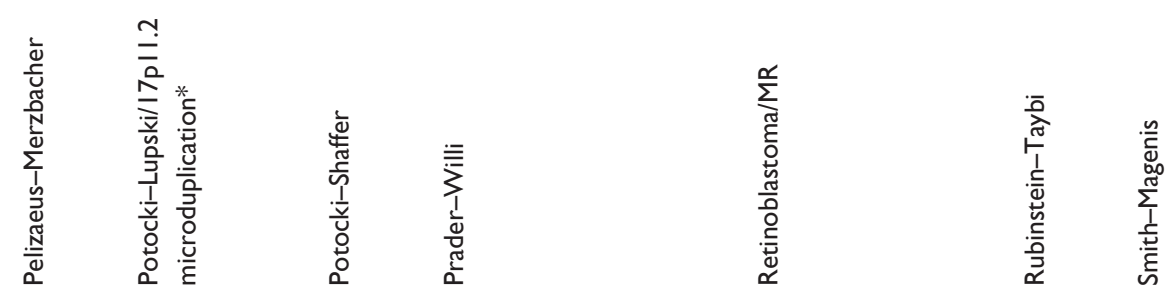


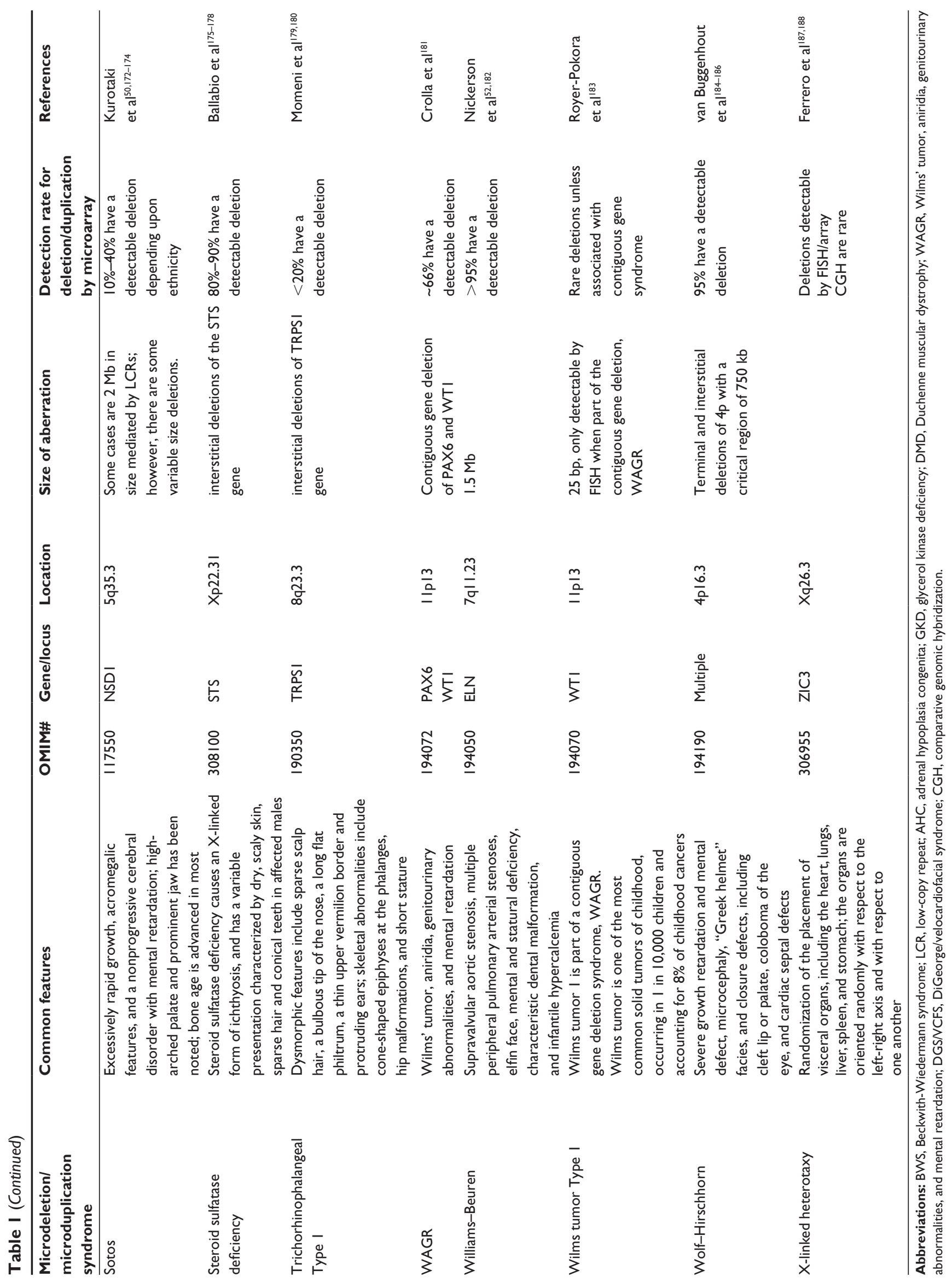




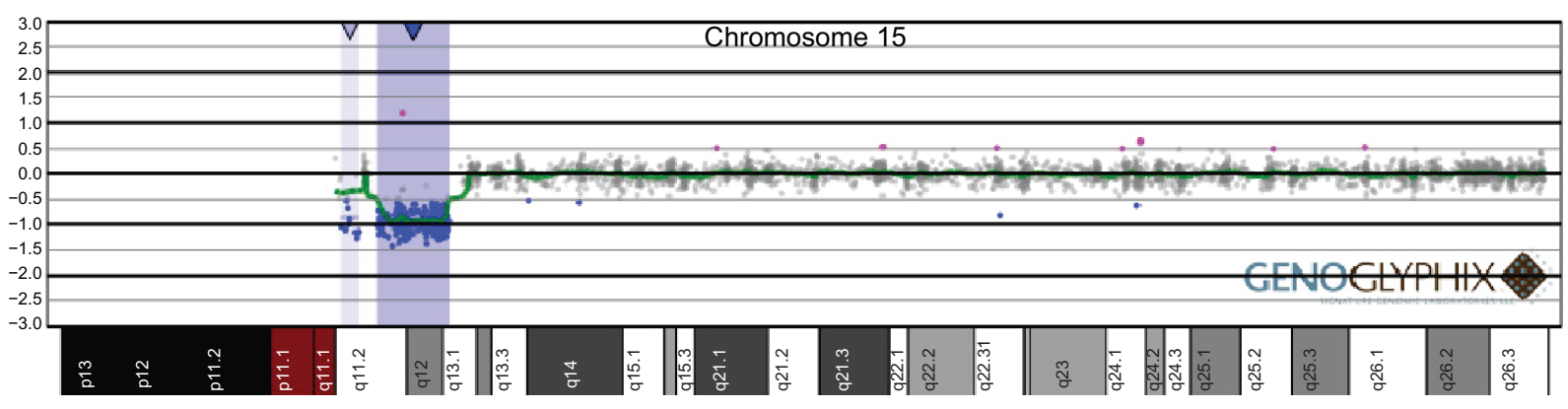

Figure I Identification by oligonucleotide microarray-based comparative genomic hybridization (aCGH) of a single-copy loss of the SNRPN/UBE3A locus at I5qI2, deletion of which is found in individuals with Prader-Willi/Angelman syndrome. Probes are ordered on the $\mathrm{x}$ axis according to physical mapping positions, with the most proximal chromosome 15 q-arm clones on the left and the most distal chromosome 15 q-arm clones on the right.

Telomeric DNA consists of tandem repeats of simple G-rich sequences that show remarkable conservation throughout eukaryotic evolution. All human chromosomes terminate with approximately $2-20 \mathrm{~kb}$ of the simple tandem repeat (TTAGGG) ${ }_{\mathrm{n}}{ }^{20}{ }^{2}$ Proximal to this telomeric repeat tract is a structurally complex region of subtelomeric DNA that can extend several hundred $\mathrm{kb}$ from the end of most chromosomes and has been shown to be highly polymorphic. ${ }^{21-24}$ Present on all but the short arms of acrocentric chromosomes 13-15 and 21-22, the unique subtelomeric regions have elicited study because they are relatively gene-rich ${ }^{25,26}$ and are prone to rearrangement by a number of mechanisms. ${ }^{27,28}$ Thus, rearrangements of the subtelomeric regions have been suggested to represent a high proportion of abnormalities in individuals with idiopathic mental retardation and, because they are gene-rich, to result in more significant clinical consequences than similarly sized imbalances elsewhere in the genome. ${ }^{17,25,29}$

Several clinically well recognized genetic disorders are associated with terminal deletions, including deletion of distal $5 p$ associated with cri du chat syndrome ${ }^{4}$ and distal deletion of $4 p$ associated with Wolf-Hirschhorn syndrome..$^{5,30}$ Deletion of the distal band of the short arm of chromosome 1 (monosomy 1p36) is the most common terminal deletion syndrome, occurring in about 1 in 5000 newborns..$^{7-9}$

The development of sets of FISH probes for the simultaneous interrogation of all the unique human subtelomeres ${ }^{29,31,32}$ has allowed for the detection of submicroscopic chromosomal abnormalities in patients with idiopathic mental retardation but without features suggestive of a particular syndrome. The largest study of subtelomeric abnormalities to date examined 11,688 cases with subtelomere FISH and detected pathogenic abnormalities in $2.6 \%{ }^{33}$ Visible deletions of every telomeric band have been identified. ${ }^{17}$ Some of these abnormalities have been identified in a sufficiently large number of patients that the abnormality can be conclusively linked to the phenotype, which could in turn be delineated by comparison of clinical features among affected individuals. ${ }^{34,35}$ Other subtelomeric abnormalities have been identified in only one or a few patients and cannot be considered syndromic until a consistent collection of clinical features is delineated.

Because the distal G-negative bands of the unique chromosome arms are gene-rich, ${ }^{25}$ deletion or retention of this region may have profound clinical consequences in individuals with telomeric imbalances. Thus, accurate delineation of the nature of the imbalance, either terminal or interstitial, is crucial for diagnosis and prognosis. Recent large-scale prospective studies using microarrays show interstitial deletions are two to three times more frequent than terminal imbalances. ${ }^{36,37}$ Recently, Ballif et al ${ }^{38}$ characterized 169 cases with subtelomeric abnormalities identified by microarray analysis. Of these 169 cases, 42 had interstitial deletions. In addition, six (3.5\%) individuals had complex rearrangements that showed deletions with duplications or additional deletions. The identification of complex rearrangements suggests chromosome abnormalities are often more complex than what was once thought.

\section{Recurrent abnormalities mediated by underlying genomic architecture}

Many recurrent chromosomal abnormalities are caused by nonallelic homologous recombination (NAHR) mediated by flanking segmental duplications. ${ }^{39-42}$ In NAHR, improper crossing-over between nonallelic, directly repeated, homologous segments (such as low-copy repeats) between sister chromatids (intrachromosomal) or between homologous chromosomes (interchromosomal) produces two reciprocal products, ie, a tandem or direct duplication and a deletion.

Such recurrent syndromes are termed "genomic disorders" and usually meet several criteria, ie, the rearrangement has breakpoints in flanking segmental duplications, the rearrangement is almost always de novo in affected individuals and is rarely seen in controls, and patients with the same 
rearrangement have similar, consistent phenotypes. ${ }^{40,41}$ The underlying genomic architecture in each of the genomic disorders identified to date is similar, ie, a stretch of unique sequence ( $50 \mathrm{~kb}-10 \mathrm{Mb}$ ) flanked by large ( $>10 \mathrm{~kb})$, highly homologous $(>95 \%)$ segmental duplications that provide the substrate for NAHR.

NAHR has been implicated in the recurrent rearrangements in Charcot-Marie-Tooth disease, ${ }^{43}$ hereditary neuropathy with liability to pressure palsies, ${ }^{44}$ and Prader-Willi, ${ }^{45}$ Angelman, ${ }^{46}$ Smith-Magenis, ${ }^{47}$ DiGeorge/velocardiofacial (DGS/VCFS), ${ }^{48}$ Williams-Beurens,${ }^{49}$ and Sotos ${ }^{50}$ syndromes (see Table 1). Almost invariably, the abnormalities identified in individuals with the same genomic disorder are of identical size. For example, the common deletion in 7q11.23 found in Williams syndrome is about $1.6 \mathrm{Mb}$ in size ${ }^{51}$ and is present in greater than $90 \%$ of patients. ${ }^{52,53}$ The common Smith-Magenis syndrome deletion within 17p11.2 is approximately $5 \mathrm{Mb}^{47,54}$ and is found in the majority of patients. ${ }^{47,55}$ Approximately $90 \%$ of individuals with DGS/ VCFS have an approximately $3 \mathrm{Mb}$ deletion at 22q11.2, and most of the remainder have an alternate distal deletion breakpoint, resulting in a smaller $1.5 \mathrm{Mb}$ deletion, and both deletions are mediated by closely related low copy repeats in the region. ${ }^{56}$ Atypical breakpoints have been reported for other recurrent rearrangements mediated by segmental duplications. For example, some of the rarer rearrangements of 17p11.2 associated with Smith-Magenis syndrome do not have breakpoints flanked by the typical paired segmental duplications, and are not associated with known genomic architectural features, ${ }^{57}$ and some of the breakpoints in the recently identified 16p11.2p12.2 microdeletion syndrome are not flanked by segmental duplications. ${ }^{16}$

Nonallelic homologous recombination predicts that reciprocal duplications of low copy repeat-mediated deletions should occur with equal frequency. ${ }^{40}$ However, duplications have been reported more rarely than expected. ${ }^{58-62}$ One explanation is that individuals with duplications usually have milder phenotypes that may not lead to clinical investigation than individuals with deletions. ${ }^{59,61-66}$ Furthermore, duplications involving segments smaller than $1.5 \mathrm{Mb}$ may be routinely missed, even by FISH of interphase nuclei. ${ }^{67}$ However, recent large population studies of individuals tested by microarray analysis have shown that the frequency of reciprocal duplications is higher than in previous studies with other cytogenetic technologies. ${ }^{68-71}$ Duplications of the common Rett syndrome gene $M E C P 2$ have been identified in males with developmental delay, ${ }^{72}$ and the reciprocal duplications of microdeletion syndromes, such as 3q29 microdeletion syndrome, ${ }^{73}$ Williams-Beuren syndrome, ${ }^{74}$ and the $22 q 11.21$ microdeletion syndrome, ${ }^{59}$ have been identified by microarray testing. The clinical significance of some of these reciprocal duplications is not known. For example, only two individuals had de novo microduplications of 3q29, whereas the remaining cases were inherited from a carrier parent. Thus, the clinical significance of these duplications is unclear, and any phenotype may be modulated by an as yet unidentified genetic modifier.

Several new syndromes, including 8p23 duplication ${ }^{75}$ and $16 \mathrm{p} 12.1$ microdeletion, ${ }^{76}$ can be transmitted from parent to child. The study of $16 \mathrm{p} 12.1$ microdeletions presents an interesting case study of the previously underappreciated complexity of genetic disorder pathogenesis. Recurrent microdeletions of $16 \mathrm{p} 12.1$ have been identified in individuals referred for genetic testing for idiopathic mental retardation and congenital anomalies, and appear to be enriched in such individuals compared with clinically normal controls. ${ }^{76}$ Almost all the 16p12.1 microdeletions identified have been inherited from a carrier parent. Carrier parents for the 16 p12.1 microdeletion are more likely to exhibit learning disability, bipolar disorder or depression, and seizures than noncarrier parents. The presence of varying degrees of learning disability in the adult family members suggests that some transmitted abnormalities are pathologic and have an underappreciated contribution to the phenotype. ${ }^{76}$

\section{Deletions of varying size may elucidate causative genes for syndromes}

Because many chromosomal alterations are large and encompass numerous genes, the ascertainment of individuals with overlapping deletions and varying clinical features may allow researchers to narrow the region in which to search for candidate genes. For example, varying-sized deletions at Xp21 comprise a contiguous gene syndrome that encompasses seven disorders, ie, adrenal hypoplasia congenita, glycerol kinase, Duchenne muscular dystrophy, McLeod phenotype, chronic granulomatous disease, retinitis pigmentosa, and ornithine transcarbamylase deficiency. The first recognized patient with an Xp21 contiguous gene deletion was diagnosed with Duchenne muscular dystrophy associated with chronic granulomatous disease, retinitis pigmentosa, and McLeod phenotype. ${ }^{77}$ Molecular studies of subsequent individuals with varyingsized deletions at Xp21 and varying phenotypes allowed for the construction of a disease gene map and the identification of causative genes for each of these disorders. ${ }^{78-81}$ 
Such an approach also allowed researchers to delineate the critical regions of trichorhinophalangeal syndrome type 1 and trichorhinophalangeal syndrome type 2, also known as Langer-Giedion syndrome. Langer-Giedion syndrome combines the features of trichorhinophalangeal syndrome type 1 and multiple exostoses type 1 . The cytogenetic basis of Langer-Giedion syndrome was unknown until high-resolution banding identified interstitial deletions in the long arm of chromosome 8 in patients with this syndrome, ${ }^{82,83}$ and the location of the deletion was subsequently determined to be $8 \mathrm{q} 24 \cdot 1 .^{84,85}$ Mapping of the deletion breakpoints in a cohort of Langer-Giedion syndrome patients showed that $75 \%$ have cytogenetically detectable deletions of $8 \mathrm{q} 24.1 .^{86}$ The identification of an individual with trichorhinophalangeal syndrome Type 1 but not exostoses and with a partial microdeletion of $8 \mathrm{q} 23^{87}$ suggested that Langer-Giedion syndrome was caused by deletion of two or more genes, disruption of one of which results in trichorhinophalangeal syndrome Type 1 and disruption of the other of which results in multiple exostoses. Buhler et al ${ }^{88}$ concluded that the Langer-Giedion syndrome is due to a deletion extending from 8q24.11 to 8q24.13, whereas trichorhinophalangeal syndrome Type 1 is caused by an even smaller deleted segment, namely, 8q24.12. Thus, it was determined that Langer-Giedion syndrome, which combines features of trichorhinophalangeal syndrome Type 1 and multiple exostoses, is a contiguous gene syndrome caused by haploinsufficiency of both TRPSI and EXT1. ${ }^{89}$

\section{Genotype-first approach to diagnosis}

Many of the recently identified syndromes have been identified through a genotype-first approach, rather than a typical phenotype-first approach. ${ }^{6}$ In the phenotype-first approach, the astute clinician would gather patients based on clinical presentation. This approach took many years to observe several rare individuals and develop a syndrome. The resulting syndromes had very consistent phenotypes among patients. In contrast, the genotype-first approach identifies patients with the same or overlapping genomic alterations and then describes the phenotypes observed. In this latter approach, the patients often display varying features, and in hindsight would not have been grouped based on clinical presentation alone.

Recently, microarrays designed to interrogate known segmental duplication "hotspots" of the genome have identified several previously unrecognized genomic disorders. Recurrent microdeletions of chromosome $10 \mathrm{q} 22.3 \mathrm{q} 23.3,{ }^{90,91} 15 \mathrm{q} 24,{ }^{13-15} 16 \mathrm{p} 11.2 \mathrm{p} 12.2,{ }^{16} 17 \mathrm{q} 21.31,{ }^{10-12}$ and $17 \mathrm{q} 23.1 \mathrm{q} 23.2^{92}$ have been identified in such a manner. In all cases, the majority of patients identified met the classical definition of a recurrent genomic disorder. The deletions were flanked by segmental duplications, the deletions were always apparently de novo in origin, and the patients had similar clinical features. ${ }^{41}$ However, the clinical features of these syndromes do not usually evoke a diagnostic Gestalt, which demonstrates the utility of the genotype-first approach in the absence of striking clinical features.

The genotype-first approach may also enable the identification of small deletions or duplications that reveal the causative genes for specific clinical features, which can aid diagnosis and prognosis. For example, researchers recently identified what is likely to be the causative gene for features of $2 \mathrm{q} 32 \mathrm{q} 33$ microdeletion syndrome. ${ }^{92}$ Individuals with the syndrome have severe mental retardation, growth retardation, dysmorphic facial features, thin and sparse hair, feeding difficulties, and cleft or high palate. Although deletions of varying sizes have been reported, the smallest region deleted in all patients contains at least seven genes. One of these genes, $S A T B 2$, is a DNA-binding protein that regulates how genes are expressed. Deletion of SATB2 has been suggested to cause the cleft or high palate of individuals with 2q32q33 microdeletion syndrome. The recent study identified three individuals with small deletions of this region, all of which spanned part of SATB2. Common clinical features among these individuals included severe developmental delay, behavioral problems, and tooth abnormalities. Interestingly, only one of the individuals had a cleft palate. Because the individuals had a portion of only one gene missing and the presence of many of the features associated with the larger microdeletion syndrome, the study authors suggested deletion of SATB2 was sufficient to cause several of the clinical features associated with $2 \mathrm{q} 32 \mathrm{q} 33$ microdeletion syndrome. ${ }^{92}$

\section{Summary}

Chromosomal disorders are the most frequent cause of mental retardation and developmental disabilities in our population. The phenotypes are often complex, and the result of a gain or loss of multiple, dosage-sensitive genes in the altered segments. The characterization of these complex phenotypes with overlapping deletions has allowed for the identification of genes causing particular features of the syndrome. The use of high-resolution technologies, such as microarrays, has allowed for the identification of new syndromes through a genotype-first approach at an unprecedented frequency never before imagined through the 
light microscope. Cytogenetics is no longer in its infancy, and has emerged a "new" genome science that, with the use of new technologies, has established the causes of mental retardation, developmental disabilities, and birth defects in our population.

\section{Disclosure}

A Theisen and LG Shaffer are employees of Signature Genomic Laboratories, a subsidiary of PerkinElmer.

\section{References}

1. Shaffer LG, Lupski JR. Molecular mechanisms for constitutional chromosomal rearrangements in humans. Annu Rev Genet. 2000;34: 297-329.

2. Hassold T, Chen N, Funkhouser J, et al. A cytogenetic study of 1000 spontaneous abortions. Ann Hum Genet. 1980;44(Pt 2):151-178.

3. Schmickel RD. Contiguous gene syndromes: a component of recognizable syndromes. J Pediatr. 1986;109(2):231-241.

4. Lejeune L, Lafourcade J, de Grouchy J, et al. Partial deletion of the short arm of chromosome 5. Individualization of a new morbid state. Sem Hop Paris. 1964;18:1069-1079.

5. Wolf U, Reinwein H, Porsch R, Schroter R, Baitsch H. Deficiency on the short arms of a chromosome No. 4. Humangenetik. 1965;1:397-413.

6. Shaffer LG, Theisen A, Bejjani BA, et al. The discovery of microdeletion syndromes in the post-genomic era: review of the methodology and characterization of a new 1q41q42 microdeletion syndrome. Genet Med. 2007;9(9):607-616.

7. Gajecka M, Mackay KL, Shaffer LG. Monosomy 1p36 deletion syndrome. Am J Med Genet C Semin Med Genet. 2007;145C(4):346-356.

8. Shapira SK, McCaskill C, Northrup H, et al. Chromosome 1p36 deletions: the clinical phenotype and molecular characterization of a common newly delineated syndrome. Am J Hum Genet. 1997;61(3):642-650.

9. Slavotinek A, Shaffer LG, Shapira SK. Monosomy 1p36. J Med Genet. 1999;36(9):657-663.

10. Koolen DA, Vissers LE, Pfundt R, et al. A new chromosome 17q21.31 microdeletion syndrome associated with a common inversion polymorphism. Nat Genet. 2006;38(9):999-1001.

11. Sharp AJ, Hansen S, Selzer RR, et al. Discovery of previously unidentified genomic disorders from the duplication architecture of the human genome. Nat Genet. 2006;38(9):1038-1042.

12. Shaw-Smith C, Pittman AM, Willatt L, et al. Microdeletion encompassing MAPT at chromosome 17q21.3 is associated with developmental delay and learning disability. Nat Genet. 2006;38(9):1032-1037.

13. Klopocki E, Graul-Neumann LM, Grieben U, et al. A further case of the recurrent $15 \mathrm{q} 24$ microdeletion syndrome, detected by array CGH. Eur J Pediatr. 2008;167(8):903-908.

14. Sharp AJ, Selzer RR, Veltman JA, et al. Characterization of a recurrent 15q24 microdeletion syndrome. Hum Mol Genet. 2007;16(5): $567-572$.

15. Marshall CR, Noor A, Vincent JB, et al. Structural variation of chromosomes in autism spectrum disorder. Am J Hum Genet. 2008;82(2):477-488.

16. Ballif BC, Hornor SA, Jenkins E, et al. Discovery of a previously unrecognized microdeletion syndrome of 16p11.2-16p12.2. Nat Genet. 2007;39(9):1071-1073.

17. Borgaonkar DS. Chromosomal Variation in Man. A Catalog of Chromosomal Variants and Anomalies. 4th ed. New York, NY: Alan R. Liss, Inc.; 1984.

18. McClintock B. The stability of broken ends of chromosomes in Zea mays. Genetics. 1941;26:234-282.

19. Cooper JP. Telomere transitions in yeast: the end of the chromosome as we know it. Curr Opin Genet Dev. 2000;10(2):169-177.
20. Moyzis RK, Buckingham JM, Cram LS, et al. A highly conserved repetitive DNA sequence, (TTAGGG)n, present at the telomeres of human chromosomes. Proc Natl Acad Sci U S A. 1988;85(18):6622-6626.

21. Brown WR, MacKinnon PJ, Villasante A, Spurr N, Buckle VJ, Dobson MJ. Structure and polymorphism of human telomere-associated DNA. Cell. 1990;63(1):119-132.

22. Cross SH, Allshire RC, McKay SJ, McGill NI, Cooke HJ. Cloning of human telomeres by complementation in yeast. Nature. 1989; 338(6218):771-774.

23. Flint J, Bates GP, Clark K, et al. Sequence comparison of human and yeast telomeres identifies structurally distinct subtelomeric domains. Hum Mol Genet. 1997;6(8):1305-1313.

24. Riethman H, Ambrosini A, Castaneda C, et al. Mapping and initial analysis of human subtelomeric sequence assemblies. Genome Res. 2004;14(1):18-28.

25. Saccone S, de Sario A, Della Valle G, Bernardi G. The highest gene concentrations in the human genome are in telomeric bands of metaphase chromosomes. Proc Natl Acad Sci U S A. 1992;89(11): 4913-4917.

26. Saccone S, de Sario A, Wiegant J, Raap AK, Della Valle G, Bernardi G. Correlations between isochores and chromosomal bands in the human genome. Proc Natl Acad Sci U S A. 1993;90(24):11929-11933.

27. Ballif BC, Wakui K, Gajecka M, Shaffer LG. Translocation breakpoint mapping and sequence analysis in three monosomy 1 p36 subjects with $\operatorname{der}(1) t(1 ; 1)(\mathrm{p} 36 ; \mathrm{q} 44)$ suggest mechanisms for telomere capture in stabilizing de novo terminal rearrangements. Hum Genet. 2004;114(2): 198-206.

28. Ballif BC, Yu W, Shaw CA, Kashork CD, Shaffer LG. Monosomy $1 \mathrm{p} 36$ breakpoint junctions suggest pre-meiotic breakage-fusion-bridge cycles are involved in generating terminal deletions. Hum Mol Genet. 2003;12(17):2153-2165.

29. A complete set of human telomeric probes and their clinical application. National Institutes of Health and Institute of Molecular Medicine collaboration. Nat Genet. 1996;14(1):86-89.

30. Hirschhorn K, Cooper HL, Firschein IL. Deletion of short arms of chromosomes 4-5 in a child with defects of midline fusion. Humangenetik. $1965 ; 1: 479-482$.

31. Flint J, Wilkie AO, Buckle VJ, Winter RM, Holland AJ, McDermid HE. The detection of subtelomeric chromosomal rearrangements in idiopathic mental retardation. Nat Genet. 1995;9(2):132-140.

32. Knight SJ, Horsley SW, Regan R, et al. Development and clinical application of an innovative fluorescence in situ hybridization technique which detects submicroscopic rearrangements involving telomeres. Eur J Hum Genet. 1997;5(1):1-8.

33. Ravnan JB, Tepperberg JH, Papenhausen P, et al. Subtelomere FISH analysis of 11688 cases: an evaluation of the frequency and pattern of subtelomere rearrangements in individuals with developmental disabilities. J Med Genet. 2006;43(6):478-489.

34. Ning Y, Rosenberg M, Biesecker LG, Ledbetter DH. Isolation of the human chromosome 22q telomere and its application to detection of cryptic chromosomal abnormalities. Hum Genet. 1996;97(6): 765-769.

35. Phelan MC, Rogers RC, Saul RA, et al. 22q13 deletion syndrome. Am J Med Genet. 2001;101(2):91-99.

36. Shaw-Smith C, Redon R, Rickman L, et al. Microarray based comparative genomic hybridisation (array-CGH) detects submicroscopic chromosomal deletions and duplications in patients with learning disability/mental retardation and dysmorphic features. $J$ Med Genet. 2004; 41(4):241-248.

37. Vissers LE, de Vries BB, Osoegawa K, et al. Array-based comparative genomic hybridization for the genomewide detection of submicroscopic chromosomal abnormalities. Am J Hum Genet. 2003;73(6): 1261-1270.

38. Ballif BC, Sulpizio SG, Lloyd RM, et al. The clinical utility of enhanced subtelomeric coverage in array CGH. Am JMed Genet A. 2007;143A(16): $1850-1857$. 
39. Shaffer LG, Ledbetter DH, Lupski JR. Molecular cytogenetics of contiguous gene syndromes: mechanisms and consequences of gene dosage imbalance In: Scriver CR, Beaudet AL, Sly WS, et al, editors. Metabolic and Molecular Basis of Inherited Disease. Vol 1. 8th ed. New York, NY: McGraw Hill; 2001:1291-1324.

40. Lupski JR. Genomic disorders: structural features of the genome can lead to DNA rearrangements and human disease traits. Trends Genet. 1998;14(10):417-422.

41. Mefford HC, Eichler EE. Duplication hotspots, rare genomic disorders, and common disease. Curr Opin Genet Dev. 2009;19(3):196-204.

42. Stankiewicz P, Lupski JR. Genome architecture, rearrangements and genomic disorders. Trends Genet. 2002;18(2):74-82.

43. Lupski JR, de Oca-Luna RM, Slaugenhaupt S, et al. DNA duplication associated with Charcot-Marie-Tooth disease type 1A. Cell. 1991;66(2): 219-232.

44. Chance PF, Alderson MK, Leppig KA, et al. DNA deletion associated with hereditary neuropathy with liability to pressure palsies. Cell. 1993; 72(1):143-151.

45. Carrozzo R, Rossi E, Christian SL, et al. Inter- and intrachromosomal rearrangements are both involved in the origin of 15q11-15q13 deletions in Prader-Willi syndrome. Am J Hum Genet. 1997;61(1):228-231.

46. Amos-Landgraf JM, Ji Y, Gottlieb W, et al. Chromosome breakage in the Prader-Willi and Angelman syndromes involves recombination between large, transcribed repeats at proximal and distal breakpoints. Am J Hum Genet. 1999;65(2):370-386.

47. Chen KS, Manian P, Koeuth T, et al. Homologous recombination of a flanking repeat gene cluster is a mechanism for a common contiguous gene deletion syndrome. Nat Genet. 1997;17(2):154-163.

48. Edelmann L, Pandita RK, Spiteri E, et al. A common molecular basis for rearrangement disorders on chromosome 22q11. Hum Mol Genet. 1999;8(7):1157-1167.

49. Perez Jurado LA, Wang YK, Peoples R, Coloma A, Cruces J, Francke U. A duplicated gene in the breakpoint regions of the 7q11.23 WilliamsBeuren syndrome deletion encodes the initiator binding protein TFII-I and BAP-135, a phosphorylation target of BTK. Hum Mol Genet. 1998; 7(3):325-334.

50. Kurotaki N, Harada N, Shimokawa O, et al. Fifty microdeletions among 112 cases of Sotos syndrome: low copy repeats possibly mediate the common deletion. Hum Mutat. 2003;22(5):378-387.

51. Peoples R, Franke Y, Wang YK, et al. A physical map, including a BAC/ PAC clone contig, of the Williams-Beuren syndrome - deletion region at 7q11.23. Am J Hum Genet. 2000;66(1):47-68.

52. Nickerson E, Greenberg F, Keating MT, McCaskill C, Shaffer LG Deletions of the elastin gene at $7 \mathrm{q} 11.23$ occur in approximately $90 \%$ of patients with Williams syndrome. Am J Hum Genet. 1995;56(5): $1156-1161$.

53. Wu YQ, Nickerson E, Shaffer LG, Keppler-Noreuil K, Muilenburg A. A case of Williams syndrome with a large, visible cytogenetic deletion. J Med Genet. 1999;36(12):928-932.

54. Trask BJ, Mefford H, van den Engh G, et al. Quantification by flow cytometry of chromosome-17 deletions in Smith-Magenis syndrome patients. Hum Genet. 1996;98(6):710-718.

55. Juyal RC, Figuera LE, Hauge X, et al. Molecular analyses of $17 \mathrm{p} 11.2$ deletions in 62 Smith-Magenis syndrome patients. Am J Hum Genet. 1996;58(5):998-1007.

56. Shaikh TH, Kurahashi H, Saitta SC, et al. Chromosome 22-specific low copy repeats and the 22q11.2 deletion syndrome: genomic organization and deletion endpoint analysis. Hum Mol Genet. 2000;9(4): 489-501.

57. Stankiewicz P, Shaw CJ, Dapper JD, et al. Genome architecture catalyzes nonrecurrent chromosomal rearrangements. Am J Hum Genet. 2003;72(5):1101-1116.

58. Potocki L, Chen KS, Park SS, et al. Molecular mechanism for duplication 17p11.2- the homologous recombination reciprocal of the SmithMagenis microdeletion. Nat Genet. 2000;24(1):84-87.
59. Ensenauer RE, Adeyinka A, Flynn HC, et al. Microduplication 22q11.2, an emerging syndrome: clinical, cytogenetic, and molecular analysis of thirteen patients. Am J Hum Genet. 2003;73(5):1027-1040.

60. Hassed SJ, Hopcus-Niccum D, Zhang L, Li S, Mulvihill JJ. A new genomic duplication syndrome complementary to the velocardiofacial (22q11 deletion) syndrome. Clin Genet. 2004;65(5):400-404.

61. Yobb TM, Somerville MJ, Willatt L, et al. Microduplication and triplication of 22q11.2: a highly variable syndrome. Am J Hum Genet. 2005;76(5):865-876.

62. Somerville MJ, Mervis CB, Young EJ, et al. Severe expressive-language delay related to duplication of the Williams-Beuren locus. $N$ Engl J Med. 2005;353(16):1694-1701.

63. Brewer C, Holloway S, Zawalnyski P, Schinzel A, FitzPatrick D. A chromosomal deletion map of human malformations. Am J Hum Genet. 1998;63(4):1153-1159.

64. Brewer C, Holloway S, Zawalnyski P, Schinzel A, FitzPatrick D. A chromosomal duplication map of malformations: regions of suspected haplo- and triplolethality - and tolerance of segmental aneuploidy - in humans. Am J Hum Genet. 1999;64(6):1702-1708.

65. Berg JS, Brunetti-Pierri N, Peters SU, et al. Speech delay and autism spectrum behaviors are frequently associated with duplication of the 7q11.23 Williams-Beuren syndrome region. Genet Med. 2007;9(7): 427-441.

66. Potocki L, Bi W, Treadwell-Deering D, et al. Characterization of Potocki-Lupski syndrome (dup(17)(p11.2p11.2)) and delineation of a dosage-sensitive critical interval that can convey an autism phenotype. Am J Hum Genet. 2007;80(4):633-649.

67. Shaffer LG, Kennedy GM, Spikes AS, Lupski JR. Diagnosis of CMT1A duplications and HNPP deletions by interphase FISH: implications for testing in the cytogenetics laboratory. Am J Med Genet. 1997;69(3): 325-331.

68. Shaffer LG, Bejjani BA, Torchia B, Kirkpatrick S, Coppinger J, Ballif BC. The identification of microdeletion syndromes and other chromosome abnormalities: Cytogenetic methods of the past, new technologies for the future. Am J Med Genet C Semin Med Genet. 2007;145C(4): 335-345.

69. Shaffer LG, Kashork CD, Saleki R, et al. Targeted genomic microarray analysis for identification of chromosome abnormalities in 1500 consecutive clinical cases. J Pediatr. 2006;149(1):98-102.

70. Lu X, Shaw CA, Patel A, et al. Clinical implementation of chromosomal microarray analysis: summary of 2513 postnatal cases. PLOS ONE. 2007;2(3):e327.

71. de Vries BB, Pfundt R, Leisink M, et al. Diagnostic genome profiling in mental retardation. Am J Hum Genet. 2005;77(4):606-616.

72. del Gaudio D, Fang P, Scaglia F, et al. Increased MECP2 gene copy number as the result of genomic duplication in neurodevelopmentally delayed males. Genet Med. 2006;8(12):784-792.

73. Ballif BC, Theisen A, Coppinger J, et al. Expanding the clinical phenotype of the 3q29 microdeletion syndrome and characterization of the reciprocal microduplication. Mol Cytogenet. 2008;1(1):8.

74. Kriek M, White SJ, Szuhai K, et al. Copy number variation in regions flanked (or unflanked) by duplicons among patients with developmental delay and/or congenital malformations; detection of reciprocal and partial Williams-Beuren duplications. Eur J Hum Genet. 2006; 14(2):180-189.

75. Barber JC, Maloney VK, Huang S, et al. 8p23.1 duplication syndrome; a novel genomic condition with unexpected complexity revealed by array CGH. Eur J Hum Genet. 2008;16(1):18-27.

76. Girirajan S, Rosenfeld JA, Cooper GM, et al. A recurrent 16p12.1 microdeletion supports a two-hit model for severe developmental delay. Nat Genet. 2010;42(3):203-209.

77. Francke U, Ochs HD, de Martinville B, et al. Minor Xp21 chromosome deletion in a male associated with expression of Duchenne muscular dystrophy, chronic granulomatous disease, retinitis pigmentosa, and McLeod syndrome. Am J Hum Genet. 1985;37(2):250-267.

78. Lindgren V, de Martinville B, Horwich AL, Rosenberg LE, Francke U. Human ornithine transcarbamylase locus mapped to band Xp21.1 near the Duchenne muscular dystrophy locus. Science. 1984;226(4675): 698-700. 
79. Monaco AP, Neve RL, Colletti-Feener C, Bertelson CJ, Kurnit DM, Kunkel LM. Isolation of candidate cDNAs for portions of the Duchenne muscular dystrophy gene. Nature. 1986;323(6089):646-650.

80. Royer-Pokora B, Kunkel LM, Monaco AP, et al. Cloning the gene for an inherited human disorder - chronic granulomatous disease - on the basis of its chromosomal location. Nature. 1986;322(6074):32-38.

81. Sargent CA, Affara NA, Bentley E, et al. Cloning of the X-linked glycerol kinase deficiency gene and its identification by sequence comparison to the Bacillus subtilis homologue. Hum Mol Genet. 1993; 2(2):97-106.

82. Buhler EM, Buhler UK, Stalder GR, Jani L, Jurik LP. Chromosome deletion and multiple cartilaginous exostoses. Eur J Pediatr. 1980;133(2): 163-166.

83. Pfeiffer RA. Langer-Giedion syndrome and additional congenital malformations with interstitial deletion of the long arm of chromosome 8 46, XY, del 8 (q 13-22). Clin Genet. 1980;18(2):142-146.

84. Langer LO Jr, Krassikoff N, Laxova R, et al. The tricho-rhino-phalangeal syndrome with exostoses (or Langer-Giedion syndrome): four additional patients without mental retardation and review of the literature. Am J Med Genet. 1984;19(1):81-112.

85. Bowen P, Biederman B, Hoo JJ. The critical segment for the LangerGiedion syndrome: 8q24.11-8q24.12. Ann Genet. 1985;28(4): 224-227.

86. Ludecke HJ, Johnson C, Wagner MJ, et al. Molecular definition of the shortest region of deletion overlap in the Langer-Giedion syndrome. Am J Hum Genet. 1991;49(6):1197-1206.

87. Goldblatt J, Smart RD. Tricho-rhino-phalangeal syndrome without exostoses, wih an interstitial deletion of 8q23. Clin Genet. 1986;29(5): 434-438.

88. Buhler EM, Buhler UK, Beutler C, Fessler R. A final word on the tricho-rhino-phalangeal syndromes. Clin Genet. 1987;31(4):273-275.

89. Ludecke HJ, Wagner MJ, Nardmann J, et al. Molecular dissection of a contiguous gene syndrome: localization of the genes involved in the Langer-Giedion syndrome. Hum Mol Genet. 1995;4(1):31-36.

90. Alliman S, Coppinger J, Marcadier J, et al. Clinical and molecular characterization of individuals with recurrent genomic disorder at 10q22.3q23.2. Clin Genet. 2010

91. Balciuniene J, Feng N, Iyadurai K, et al. Recurrent 10q22-10q23 Deletions: A Genomic Disorder on 10q Associated with Cognitive and Behavioral Abnormalities. Am J Hum Genet. 2007;80(5):938-947.

92. Rosenfeld JA, Ballif BC, Lucas A, et al. Small deletions of SATB2 cause some of the clinical features of the 2q33.1 microdeletion syndrome. PLoS One. 2009;4(8):e6568.

93. Heilstedt HA, Ballif BC, Howard LA, et al. Physical map of $1 \mathrm{p} 36$, placement of breakpoints in monosomy $1 \mathrm{p} 36$, and clinical characterization of the syndrome. Am J Hum Genet. 2003;72(5):1200-1212.

94. Heilstedt HA, Ballif BC, Howard LA, Kashork CD, Shaffer LG. Population data suggest that deletions of $1 \mathrm{p} 36$ are a relatively common chromosome abnormality. Clin Genet. 2003;64(4):310-316.

95. Yu W, Ballif BC, Kashork CD, et al. Development of a comparative genomic hybridization microarray and demonstration of its utility with 25 well-characterized $1 \mathrm{p} 36$ deletions. Hum Mol Genet. 2003;12(17):2145-2152.

96. Klopocki E, Schulze H, Strauss G, et al. Complex inheritance pattern resembling autosomal recessive inheritance involving a microdeletion in thrombocytopenia-absent radius syndrome. Am J Hum Genet. 2007; 80(2):232-240.

97. Rare chromosomal deletions and duplications increase risk of schizophrenia. Nature. 2008;455(7210):237-241.

98. Stefansson H, Rujescu D, Cichon S, et al. Large recurrent microdeletions associated with schizophrenia. Nature. 2008;455(7210):232-236.

99. Brunetti-Pierri N, Berg JS, Scaglia F, et al. Recurrent reciprocal 1q21.1 deletions and duplications associated with microcephaly or macrocephaly and developmental and behavioral abnormalities. Nat Genet. 2008;40(12):1466-1471.
100. Mefford HC, Sharp AJ, Baker C, et al. Recurrent rearrangements of chromosome 1q21.1 and variable pediatric phenotypes. $N$ Engl J Med. 2008;359(16):1685-1699.

101. Willatt L, Cox J, Barber J, et al. 3q29 microdeletion syndrome: clinical and molecular characterization of a new syndrome. Am J Hum Genet. 2005;77(1):154-160.

102. Wang NJ, Liu D, Parokonny AS, Schanen NC. High-resolution molecular characterization of $15 \mathrm{q} 11-15 \mathrm{q} 13$ rearrangements by array comparative genomic hybridization (array CGH) with detection of gene dosage. Am J Hum Genet. 2004;75(2):267-281.

103. Cook EH Jr, Lindgren V, Leventhal BL, et al. Autism or atypical autism in maternally but not paternally derived proximal $15 \mathrm{q}$ duplication. $\mathrm{Am}$ J Hum Genet. 1997;60(4):928-934.

104. Sharp AJ, Mefford HC, Li K, et al. A recurrent 15q13.3 microdeletion syndrome associated with mental retardation and seizures. Nat Genet. 2008;40(3):322-328.

105. Miller DT, Shen Y, Weiss LA, et al. Microdeletion/duplication at $15 \mathrm{q} 13.2 \mathrm{q} 13.3$ among individuals with features of autism and other neuropsychiatric disorders. J Med Genet. 2009;46(4):242-248.

106. Slavotinek AM. Novel microdeletion syndromes detected by chromosome microarrays. Hum Genet. 2008;124(1):1-17.

107. Ballif BC, Theisen A, Rosenfeld JA, et al. Identification of a recurrent microdeletion at $17 \mathrm{q} 23.1 \mathrm{q} 23.2$ flanked by segmental duplications associated with heart defects and limb abnormalities. Am J Hum Genet. 2010;86(3):454-461.

108. Ben-Shachar S, Ou Z, Shaw CA, et al. 22q11.2 distal deletion: a recurrent genomic disorder distinct from DiGeorge syndrome and velocardiofacial syndrome. Am J Hum Genet. 2008;82(1):214-221.

109. Rauch A, Zink S, Zweier C, et al. Systematic assessment of atypical deletions reveals genotype-phenotype correlation in 22q11.2. J Med Genet. 2005;42(11):871-876.

110. Wentzel C, Fernstrom M, Ohrner Y, Anneren G, Thuresson AC. Clinical variability of the 22q11.2 duplication syndrome. Eur J Med Genet. 2008;51(6):501-510.

111. Alberti A, Romano C, Falco M, et al. 1.5 Mb de novo 22q11.21 microduplication in a patient with cognitive deficits and dysmorphic facial features. Clin Genet. 2007;71(2):177-182.

112. Torres-Juan L, Rosell J, Morla M, et al. Mutations in TBX1 genocopy the 22q11.2 deletion and duplication syndromes: a new susceptibility factor for mental retardation. Eur J Hum Genet. 2007;15(6):658-663.

113. Anderlid BM, Schoumans J, Anneren G, et al. FISH-mapping of a 100-kb terminal 22q13 deletion. Hum Genet. 2002;110(5): $439-443$.

114. Luciani JJ, de Mas P, Depetris D, et al. Telomeric 22q13 deletions resulting from rings, simple deletions, and translocations: cytogenetic, molecular, and clinical analyses of 32 new observations. J Med Genet. 2003;40(9):690-696.

115. Okamoto N, Kubota T, Nakamura Y, et al. 22q13 Microduplication in two patients with common clinical manifestations: a recognizable syndrome? Am J Med Genet A. 2007;143A(23):2804-2809.

116. Guo W, Mason JS, Stone CG Jr, et al. Diagnosis of X-linked adrenal hypoplasia congenita by mutation analysis of the DAX1 gene. JAMA. 1995;274(4):324-330.

117. Peter M, Viemann M, Partsch CJ, Sippell WG. Congenital adrenal hypoplasia: clinical spectrum, experience with hormonal diagnosis, and report on new point mutations of the DAX-1 gene. J Clin Endocrinol Metab. 1998;83(8):2666-2674.

118. Krantz ID, Colliton RP, Genin A, et al. Spectrum and frequency of jagged1 (JAG1) mutations in Alagille syndrome patients and their families. Am J Hum Genet. 1998;62(6):1361-1369.

119. Spinner NB, Colliton RP, Crosnier C, Krantz ID, Hadchouel M, Meunier-Rotival M. Jagged1 mutations in alagille syndrome. Hum Mutat. 2001;17(1):18-33.

120. Magenis RE, Brown MG, Lacy DA, Budden S, LaFranchi S. Is Angelman syndrome an alternate result of del(15)(q11q13)? Am J Med Genet. 1987;28(4):829-838. 
121. Zackowski JL, Nicholls RD, Gray BA, et al. Cytogenetic and molecular analysis in Angelman syndrome. Am J Med Genet. 1993;46(1):7-11.

122. Henry I, Puech A, Riesewijk A, et al. Somatic mosaicism for partial paternal isodisomy in Wiedemann-Beckwith syndrome: a postfertilization event. Eur J Hum Genet. 1993;1(1):19-29.

123. Li M, Squire JA, Weksberg R. Molecular genetics of WiedemannBeckwith syndrome. Am J Med Genet. 1998;79(4):253-259.

124. Slavotinek A, Gaunt L, Donnai D. Paternally inherited duplications of 11p15.5 and Beckwith-Wiedemann syndrome. J Med Genet. 1997; 34(10):819-826.

125. Bartsch O, Rasi S, Hoffmann K, Blin N. FISH of supernumerary marker chromosomes (SMCs) identifies six diagnostically relevant intervals on chromosome 22q and a novel type of bisatellited SMC(22). Eur J Hum Genet. 2005;13(5):592-598.

126. Johnson A, Minoshima S, Asakawa S, et al. A 1.5-Mb contig within the cat eye syndrome critical region at human chromosome 22q11.2. Genomics. 1999;57(2):306-309.

127. Rosias PR, Sijstermans JM, Theunissen PM, et al. Phenotypic variability of the cat eye syndrome. Case report and review of the literature. Genet Couns. 2001;12(3):273-282.

128. Inoue K, Dewar K, Katsanis N, et al. The 1.4-Mb CMT1A duplication/ HNPP deletion genomic region reveals unique genome architectural features and provides insights into the recent evolution of new genes. Genome Res. 2001;11(6):1018-1033.

129. Blair IP, Nash J, Gordon MJ, Nicholson GA. Prevalence and origin of de novo duplications in Charcot-Marie-Tooth disease type 1A: first report of a de novo duplication with a maternal origin. Am J Hum Genet. 1996;58(3):472-476.

130. Vissers LE, van Ravenswaaij CM, Admiraal R, et al. Mutations in a new member of the chromodomain gene family cause CHARGE syndrome. Nat Genet. 2004;36(9):955-957.

131. Church DM, Yang J, Bocian M, Shiang R, Wasmuth JJ. A high-resolution physical and transcript map of the Cri du chat region of human chromosome 5p. Genome Res. 1997;7(8):787-801.

132. Mainardi PC, Perfumo C, Cali A, et al. Clinical and molecular characterisation of 80 patients with $5 \mathrm{p}$ deletion: genotype-phenotype correlation. J Med Genet. 2001;38(3):151-158.

133. Zhang X, Snijders A, Segraves R, et al. High-resolution mapping of genotype-phenotype relationships in cri du chat syndrome using array comparative genomic hybridization. Am J Hum Genet. 2005;76(2):312-326.

134. Mantripragada KK, Tapia-Paez I, Blennow E, Nilsson P, Wedell A, Dumanski JP. DNA copy-number analysis of the 22q11 deletionsyndrome region using array-CGH with genomic and PCR-based targets. Int J Mol Med. 2004;13(2):273-279.

135. Yagi H, Furutani Y, Hamada H, et al. Role of TBX1 in human del22q11.2 syndrome. Lancet. 2003;362(9393):1366-1373.

136. Berend SA, Spikes AS, Kashork CD, et al. Dual-probe fluorescence in situ hybridization assay for detecting deletions associated with VCFS/ DiGeorge syndrome I and DiGeorge syndrome II loci. Am J Med Genet. 2000;91(4):313-317.

137. van Esch $H$, Groenen $P$, Daw $S$, et al. Partial DiGeorge syndrome in two patients with a 10p rearrangement. Clin Genet. 1999;55(4):269-276.

138. del Gaudio D, Yang Y, Boggs BA, et al. Molecular diagnosis of Duchenne/Becker muscular dystrophy: enhanced detection of dystrophin gene rearrangements by oligonucleotide array-comparative genomic hybridization. Hum Mutat. 2008;29(9):1100-1107.

139. Bovolenta M, Neri M, Fini S, et al. A novel custom high densitycomparative genomic hybridization array detects common rearrangements as well as deep intronic mutations in dystrophinopathies. $B M C$ Genomics. 2008;9:572.

140. Srour M, Bejjani BA, Rorem EA, Hall N, Shaffer LG, Shevell MI An instructive case of an 8-year-old boy with intellectual disability. Semin Pediatr Neurol. 2008;15(4):154-155; discussion 155-156.

141. Johnston JJ, Olivos-Glander I, Turner J, et al. Clinical and molecular delineation of the Greig cephalopolysyndactyly contiguous gene deletion syndrome and its distinction from acrocallosal syndrome. Am J Med Genet A. 2003;123A(3):236-242.
142. Sargent CA, Kidd A, Moore S, Dean J, Besley GT, Affara NA. Five cases of isolated glycerol kinase deficiency, including two families: failure to find genotype:phenotype correlation. J Med Genet. 2000;37(6):434-441.

143. Lenssen PP, Gabreels-Festen AA, Valentijn LJ, et al. Hereditary neuropathy with liability to pressure palsies. Phenotypic differences between patients with the common deletion and a PMP22 frame shift mutation. Brain. 1998;121(Pt 8):1451-1458.

144. Lopes J, Tardieu S, Silander K, et al. Homologous DNA exchanges in humans can be explained by the yeast double-strand break repair model: a study of $17 \mathrm{p} 11.2$ rearrangements associated with CMT1A and HNPP. Hum Mol Genet. 1999;8(12):2285-2292.

145. Le Guern E, Sturtz F, Gugenheim M, et al. Detection of deletion within $17 \mathrm{p} 11.2$ in 7 French families with hereditary neuropathy with liability to pressure palsies (HNPP). Cytogenet Cell Genet. 1994;65(4): 261-264.

146. Ballabio A, Parenti G, Tippett P, et al. X-linked ichthyosis, due to steroid sulphatase deficiency, associated with Kallmann syndrome (hypogonadotropic hypogonadism and anosmia): linkage relationships with Xg and cloned DNA sequences from the distal short arm of the X chromosome. Hum Genet. 1986;72(3):237-240.

147. Hardelin JP, Levilliers J, Young J, et al. Xp22.3 deletions in isolated familial Kallmann's syndrome. J Clin Endocrinol Metab. 1993;76(4): $827-831$

148. Sato N, Katsumata N, Kagami M, et al. Clinical assessment and mutation analysis of Kallmann syndrome 1 (KAL1) and fibroblast growth factor receptor 1 (FGFR1, or KAL2) in five families and 18 sporadic patients. J Clin Endocrinol Metab. 2004;89(3):1079-1088.

149. Ahn J, Ludecke HJ, Lindow S, et al. Cloning of the putative tumour suppressor gene for hereditary multiple exostoses (EXT1). Nat Genet. 1995;11(2):137-143.

150. Nardmann J, Tranebjaerg L, Horsthemke B, Ludecke HJ. The tricho-rhino-phalangeal syndromes: frequency and parental origin of 8q deletions. Hum Genet. 1997;99(5):638-643.

151. Kayserili H, Cox TC, Cox LL, et al. Molecular characterisation of a new case of microphthalmia with linear skin defects (MLS). J Med Genet. 2001;38(6):411-417.

152. Prakash SK, Cormier TA, McCall AE, et al. Loss of holocytochrome c-type synthetase causes the male lethality of X-linked dominant microphthalmia with linear skin defects (MLS) syndrome. Hum Mol Genet. 2002;11(25):3237-3248.

153. Zvulunov A, Kachko L, Manor E, Shinwell E, Carmi R. Reticulolinear aplasia cutis congenita of the face and neck: a distinctive cutaneous manifestation in several syndromes linked to Xp22. Br J Dermatol. 1998;138(6):1046-1052.

154. Dobyns WB, Curry CJ, Hoyme HE, Turlington L, Ledbetter DH. Clinical and molecular diagnosis of Miller-Dieker syndrome. Am J Hum Genet. 1991;48(3):584-594.

155. Ledbetter SA, Kuwano A, Dobyns WB, Ledbetter DH. Microdeletions of chromosome 17p13 as a cause of isolated lissencephaly. Am J Hum Genet. 1992;50(1):182-189.

156. Cnossen MH, van der Est MN, Breuning MH, et al. Deletions spanning the neurofibromatosis type 1 gene: implications for genotypephenotype correlations in neurofibromatosis type 1? Hum Mutat. 1997; 9(5):458-464.

157. Upadhyaya M, Ruggieri M, Maynard J, et al. Gross deletions of the neurofibromatosis type 1 (NF1) gene are predominantly of maternal origin and commonly associated with a learning disability, dysmorphic features and developmental delay. Hum Genet. 1998;102(5): 591-597.

158. Inoue $\mathrm{K}$, Osaka $\mathrm{H}$, Imaizumi $\mathrm{K}$, et al. Proteolipid protein gene duplications causing Pelizaeus-Merzbacher disease: molecular mechanism and phenotypic manifestations. Ann Neurol. 1999;45(5): 624-632.

159. Woodward K, Kendall E, Vetrie D, Malcolm S. Pelizaeus-Merzbacher disease: identification of Xq22 proteolipid-protein duplications and characterization of breakpoints by interphase FISH. Am J Hum Genet. 1998;63(1):207-217. 
160. Wakui K, Gregato G, Ballif BC, et al. Construction of a natural panel of $11 \mathrm{p} 11.2$ deletions and further delineation of the critical region involved in Potocki-Shaffer syndrome. Eur J Hum Genet. 2005;13(5): 528-540.

161. Potocki L, Shaffer LG. Interstitial deletion of 11(p11.2p12): a newly described contiguous gene deletion syndrome involving the gene for hereditary multiple exostoses (EXT2). Am J Med Genet. 1996;62(3):319-325.

162. Magenis RE, Toth-Fejel S, Allen LJ, et al. Comparison of the $15 \mathrm{q}$ deletions in Prader-Willi and Angelman syndromes: specific regions, extent of deletions, parental origin, and clinical consequences. Am J Med Genet. 1990;35(3):333-349.

163. Kuwano A, Mutirangura A, Dittrich B, et al. Molecular dissection of the Prader-Willi/Angelman syndrome region (15q11-13) by YAC cloning and FISH analysis. Hum Mol Genet. 1992;1(6):417-425.

164. Cowell JK, Hungerford J, Rutland P, Jay M. Genetic and cytogenetic analysis of patients showing reduced esterase-D levels and mental retardation from a survey of 500 individuals with retinoblastoma. Ophthalmic Paediatr Genet. 1989;10(2):117-127.

165. Richter S, Vandezande K, Chen N, et al. Sensitive and efficient detection of RB1 gene mutations enhances care for families with retinoblastoma. Am J Hum Genet. 2003;72(2):253-269.

166. Petrij F, Dauwerse HG, Blough RI, et al. Diagnostic analysis of the Rubinstein-Taybi syndrome: five cosmids should be used for microdeletion detection and low number of protein truncating mutations. J Med Genet. 2000;37(3):168-176.

167. Taine L, Goizet C, Wen ZQ, et al. Submicroscopic deletion of chromosome $16 \mathrm{p} 13.3$ in patients with Rubinstein-Taybi syndrome. Am J Med Genet. 1998;78(3):267-270.

168. Seranski P, Heiss NS, Dhorne-Pollet S, et al. Transcription mapping in a medulloblastoma breakpoint interval and Smith-Magenis syndrome candidate region: identification of 53 transcriptional units and new candidate genes. Genomics. 1999;56(1):1-11.

169. Greenberg F, Guzzetta V, Montes de Oca-Luna R, et al. Molecular analysis of the Smith-Magenis syndrome: a possible contiguous-gene syndrome associated with del(17)(p11.2). Am J Hum Genet. 1991; 49(6): 1207-1218.

170. Slager RE, Newton TL, Vlangos CN, Finucane B, Elsea SH. Mutations in RAI1 associated with Smith-Magenis syndrome. Nat Genet. 2003; 33(4):466-468.

171. Vlangos CN, Yim DK, Elsea SH. Refinement of the Smith-Magenis syndrome critical region to approximately $950 \mathrm{~kb}$ and assessment of $17 \mathrm{p} 11.2$ deletions. Are all deletions created equally? Mol Genet Metab. 2003;79(2):134-141.

172. Waggoner DJ, Raca G, Welch K, et al. NSD1 analysis for Sotos syndrome: insights and perspectives from the clinical laboratory. Genet Med. 2005;7(8):524-533.

173. Tatton-Brown K, Douglas J, Coleman K, et al. Multiple mechanisms are implicated in the generation of $5 \mathrm{q} 35$ microdeletions in Sotos syndrome. J Med Genet. 2005;42(4):307-313.
174. Turkmen S, Gillessen-Kaesbach G, Meinecke P, et al. Mutations in NSD1 are responsible for Sotos syndrome, but are not a frequent finding in other overgrowth phenotypes. Eur J Hum Genet. 2003;11(11): 858-865.

175. Ballabio A, Carrozzo R, Parenti G, et al. Molecular heterogeneity of steroid sulfatase deficiency: a multicenter study on 57 unrelated patients, at DNA and protein levels. Genomics. 1989;4(1): 36- 40 .

176. Conary JT, Lorkowski G, Schmidt B, et al. Genetic heterogeneity of steroid sulfatase deficiency revealed with cDNA for human steroid sulfatase. Biochem Biophys Res Commun. 1987;144(2): 1010-1017.

177. Kashork CD, Sutton VR, Fonda Allen JS, et al. Low or absent unconjugated estriol in pregnancy: an indicator for steroid sulfatase deficiency detectable by fluorescence in situ hybridization and biochemical analysis. Prenat Diagn. 2002;22(11):1028-1032.

178. Shapiro LJ, Yen P, Pomerantz D, Martin E, Rolewic L, Mohandas T. Molecular studies of deletions at the human steroid sulfatase locus. Proc Natl Acad Sci U S A. 1989;86(21):8477-8481.

179. Momeni P, Glockner G, Schmidt O, et al. Mutations in a new gene, encoding a zinc-finger protein, cause tricho-rhino-phalangeal syndrome type I. Nat Genet. 2000;24(1):71-74.

180. Ludecke HJ, Schaper J, Meinecke P, et al. Genotypic and phenotypic spectrum in tricho-rhino-phalangeal syndrome types I and III. Am J Hum Genet. 2001;68(1):81-91.

181. Crolla JA, van Heyningen V. Frequent chromosome aberrations revealed by molecular cytogenetic studies in patients with aniridia. Am J Hum Genet. 2002;71(5):1138-1149.

182. Lowery MC, Morris CA, Ewart A, et al. Strong correlation of elastin deletions, detected by FISH, with Williams syndrome: evaluation of 235 patients. Am J Hum Genet. 1995;57(1):49-53.

183. Royer-Pokora B, Beier M, Henzler M, et al. Twenty-four new cases of WT1 germline mutations and review of the literature: genotype/ phenotype correlations for Wilms tumor development. Am JMed Genet A. 2004;127A(3):249-257.

184. van Buggenhout G, Melotte C, Dutta B, et al. Mild Wolf-Hirschhorn syndrome: micro-array $\mathrm{CGH}$ analysis of atypical 4p16.3 deletions enables refinement of the genotype-phenotype map. J Med Genet. 2004;41(9):691-698.

185. Altherr MR, Wright TJ, Denison K, Perez-Castro AV, Johnson VP. Delimiting the Wolf-Hirschhorn syndrome critical region to 750 kilobase pairs. Am J Med Genet. 1997;71(1):47-53.

186. Battaglia A, Carey JC, Wright TJ. Wolf-Hirschhorn (4p-) syndrome. Adv Pediatr. 2001;48:75-113.

187. Ferrero GB, Gebbia M, Pilia G, et al. A submicroscopic deletion in Xq26 associated with familial situs ambiguus. Am J Hum Genet. 1997; 61(2):395-401.

188. Ware SM, Peng J, Zhu L, et al. Identification and functional analysis of ZIC3 mutations in heterotaxy and related congenital heart defects. Am J Hum Genet. 2004;74(1):93-105.
The Application of Clinical Genetics

\section{Publish your work in this journal}

The Application of Clinical Genetics is an international, peer-reviewed open access journal that welcomes laboratory and clinical findings in the field of human genetics. Specific topics include: Population genetics; Functional genetics; Natural history of genetic disease; Management of genetic disease; Mechanisms of genetic disease; Counselling and
Dovepress

ethical issues; Animal models; Pharmacogenetics; Prenatal diagnosis; Dysmorphology. The manuscript management system is completely online and includes a very quick and fair peer-review system, which is all easy to use. Visit http://www.dovepress.com/testimonials.php to read real quotes from published authors. 